\title{
PEMODELAN DINAMIKA VIRUS RUBELLA DENGAN RISIKO SINDROM RUBELLA BAWAAN
}

\author{
Modeling the Dynamics of Rubella Virus with \\ Congenital Rubella Syndrome Risks \\ Abadi $^{1^{*}}$, Rudianto Artiono ${ }^{2}$, Budi Priyo Prawoto ${ }^{3}$ \\ 1,2,3 Jurusan Matematika, FMIPA, Universitas Negeri Surabaya \\ Jln. Ketintang, Surabaya, 60231, Indonesia \\ Corresponding author e-mail: ${ }^{1 *}$ abadi@ unesa.ac.id
}

\begin{abstract}
Abstrak
Penyakit rubella adalah penyebab umum ruam dan demam pada anak-anak. Penyakit ini tergolong infeksi ringan tetapi bisa menjadi kondisi serius jika menginfeksi wanita hamil, karena dapat menyebabkan Sindrom Rubella Bawaan (CRS) pada janin. Penelitian ini bertujuan untuk memodelkan dan menganalisis penyebaran penyakit rubella guna mendapatkan gambaran tentang dinamika penularan virus rubella. Artikel ini membahas dua model penularan rubella yang melibatkan wanita usia subur dan bayi baru lahir dari wanita yang terinfeksi. Model tersebut adalah SEIR-IR tanpa memperhatikan faktor musim dan SEIR-IR dengan memperhatikan faktor musim. Hasil dari model pertama menunjukkan bahwa bifurkasi pitchfork terjadi pada solusi dinamika sistem dengan laju infeksi konstan dan kenaikan nilai laju infeksi tidak berdampak pada kejadian rubella pada bayi. Model kedua yang memperhitungkan musim memberikan dinamika yang menarik dimana pengaruh musim yang besar dapat mengarah pada dinamika solusi yang lebih kompleks.
\end{abstract}

Kata Kunci : rubella, sistem dinamik, musim, kestabilan

\begin{abstract}
Rubella is a common cause of childhood rash and fever. It is typically a mild infection but it can be serious condition in pregnant women, as it may cause Congenital Rubella Syndrome (CRS) in the fetus. The study aimed to model and analyze it in order to get picture about the dynamics of the rubella virus transmission. The paper discussed two models of rubella transmission involving child-bearing age women and newly born infants of infected mothers. The models are SEIR-IR without seasonality and SEIR-IR with seasonality. The results from the first model showed that a pitchfork bifurcation occurred in the dynamics of the solution of the system with constant infection rate and the increase of the infection rate value do not make impact to the incidence of rubella among infants. The second model involving seasonality gave interesting dynamics where big seasonality may lead to a more complex dynamics of the solution.
\end{abstract}

Keywords: rubella, dynamics, seasonality, stability.

Article info:

Submitted: $22^{\text {nd }}$ October 2020 Accepted: $20^{\text {th }}$ February 2021

How to cite this article:

Abadi, R. Artiono, B. P. Prawoto, "PEMODELAN DINAMIKA VIRUS RUBELLA DENGAN RESIKO SINDROM RUBELLA BAWAAN", BAREKENG: J. Il. Mat. \& Ter., vol. 15, no. 1, pp. 069-076, Mar. 2021.

\section{c) ()}

This work is licensed under a Creative Commons Attribution-ShareAlike 4.0 International License.

Copyright (C) 2021 Abadi, Rudianto Artiono, Budi Priyo Prawoto 


\section{PENDAHULUAN}

Infeksi rubella pada usia awal kehamilan seorang ibu dapat menyebabkan aborsi secara langsung atau Congenital Rubella Syndrome (CRS) dengan berbagai cacat lahir, seperti gangguan pendengaran, penyakit jantung bawaan, mikrosefali, katarak, global keterlambatan perkembangan, dan berbagai manifestasi permanen lainnya. [1, 2, 16, 19].

Di banyak negara, beban CRS cukup bermasalah. Di negara maju seperti Inggris, Wales, Denmark, Australia, dan Jepang, penelitian tentang penyakit menular seperti rubella dilakukan secara ekstensif dengan mempertimbangan faktor yang lebih realistis telah dilakukan oleh beberapa peneliti $[3,4,5,6]$. Dalam studinya, Fine dan Clarkson [3] menemukan bahwa parameter penularan virus meningkat tiga kali setiap tahun sesuai dengan pembukaan sekolah pada awal semester, waktu sekolah pada musim gugur, dan liburan tengah semester. Pola musim tersebut berdampak pada program vaksinasi campak nasional sehingga mereka menyarankan bahwa program tidak akan menurunkan jumlah total orang yang rentan terhadap campak di Inggris dan Wales. Sementara Olsen, et.al. [4] mempelajari enam penyakit anak termasuk rubella di Kopenhagen, Denmark. Mereka menggunakan model skema SEIR dan menggunakan pendekatan Monte Carlo untuk simulasi. Mereka menyimpulkan bahwa hasil simulasi menunjukkan persetujuan substansial dengan data aktual. Lebih lanjut, Gao, et.al. [5] menunjukkan vaksinasi selektif itu untuk anak sekolah yang diterapkan oleh pemerintah Australia pada periode 1971-88 menghasilkan penurunan 90\% dalam kejadian CRS, tetapi hanya 1 - 4\% penurunan insiden rubella. Baru-baru ini, pada 2019 Lee, et.al. [6] mempelajari model berdasarkan parameter pada data epidemi rubella di Jepang periode 2012 - 14 untuk memprediksi besarnya epidemi CRS selama 2018 - 19. Hasilnya menyimpulkan bahwa kejadian CRS diharapkan terjadi rata-rata 24 minggu setelah ibu terinfeksi oleh virus rubella dan dalam 650 kasus pada wanita pada minggu ke 5 pada tahun 2019, kasus CRS selama periode tersebut telah melebihi 13 kasus.

Beban rubella dan CRS di negara berkembang cukup berlebihan dan sebagian besar belum diatasi dengan baik. Ini tercermin dari review yang dilakukan oleh Cutts et.al. [1] berdasarkan literatur CRS dan rubella yang didapat dari negara berkembang di wilayah Organisasi Kesehatan Dunia (WHO). Informasi tentang beban CRS diperoleh dari surveilans Data dan dari serosurvei menunjukkan bahwa prevalensi rubella spesifik usia pada wanita hamil dan/atau wanita usia subur. Contoh praktik surveilans CRS yang baik dilakukan di Indonesia oleh Herini et.al. [2]. Mereka melakukan surveilans berbasis rumah sakit dan melaporkan kejadian CRS di Indonesia tinggi dengan empat cacat paling umum di antara kasus CRS yang dikonfirmasi laboratorium adalah gangguan pendengaran (100\%), katarak kongenital $(72,7 \%)$, mikrosefali $(72,7 \%)$, dan kelainan jantung bawaan $(45,5 \%)$. Mereka menyarankan pentingnya penerapan program vaksinasi program di negara tersebut. Studi rubella di Meksiko telah dilakukan oleh Metcalf et.al. [7]. Mereka menganggap rubella sebagai penyakit musiman yang data penularannya berasal dari laporan kejadian di Meksiko selama kurun waktu 20 tahun. Transmisi musiman diperkirakan dengan menggunakan model SIR time-series. Mereka menggunakan perkiraan untuk menentukan pola musim di antara wilayah yang sedang dipelajari. Hasil ini digunakan untuk mengidentifikasi populasi yang paling berisiko dan untuk pelaksanaan program vaksinasi.

Sebagian besar studi yang disebutkan di atas dan banyak studi serupa lainnya tentang rubella dan CRS menyiratkan hasil mereka pada implementasi program vaksinasi termasuk berbagai strategi dan kebijakan yang diterapkan. (Lihat $[3,5,8,9,10,18,20]$ untuk referensi). Studi ini adalah bagian pertama dari keseluruhan studi tentang pemodelan dan analisis dinamika virus rubella dengan mempertimbangkan resiko CRS dan pelaksanaan program vaksinasi, terutama untuk wanita usia subur. Studi ini lebih berfokus pada pemodelan dinamika virus rubella yang melibatkan populasi wanita usia subur dan anak yang baru lahir dari ibu yang terinfeksi rubella. Bagian kedua dari studi ini, yang akan dipublikasikan secara terpisah, memfokuskan pada pengaruh pemberian vaksinasi 2 dosis yang diterapkan pada populasi wanita.

\section{METODE PENELITIAN}

Penelitian ini merupakan studi literatur yang didukung oleh metode matematis yang diawali mengkonstruksi model matematika dari model penyebaran rubella pada populasi wanita usia subur serta pengaruhnya pada bayi yang dilahirkan wanita usia subur, yaitu bayi dengan sindrom rubella bawaan (CRS). Model dikonstruksi berdasarkan asumsi-asumsi kondisi alami dan pertimbangan medis yang selama ini berlaku pada penderita rubella. Model yang diperoleh kemudian dianalisis sebagai berikut: (1) penentuan titik-titik kritis/ekuilibrium sistem dan kestabilannya menggunakan analisis nilai eigen (linearisasi) [15, 17], 
(2) penentuan ratio reproduksi dasar sebagai ambang penyebaran penyakit, dan (3) simulasi numerik dan interpretasi epidemiologis.

\section{HASIL DAN PEMBAHASAN}

Banyak penelitian sebelumnya tentang rubella menggunakan model Susceptible-Exposed-InfectivesRecovered (SEIR) karena karakteristiknya dari virus yang telah terpapar atau tahap laten. Bagian ini menyajikan dua model SEIR-IR yang mewakili penularan virus rubella melalui ibu muda dan anak yang baru lahir dari ibu yang terinfeksi rubella.

\subsection{Model SEIR-IR}

Model pertama mengikuti standar model SEIR di [11] yang mempertimbangkan populasi terinfeksi dan sembuh yang merupakan anak baru lahir. Model SEIR merepresentasikan populasi wanita usia subur (Lihat $[5,21])$. Asumsi yang digunakan dalam model adalah sebagai berikut.

1. Populasi perempuan diasumsikan tertutup,

2. Peningkatan jumlah individu rentan disebabkan oleh angka kelahiran alami, sedangkan penurunan individu rentan disebabkan tingkat kematian alami dan penularan dari individu yang rentan yang terinfeksi ke yang terpapar atau terpapar,

3. Ada tingkat inkubasi di mana virus menularkan dari individu laten menjadi individu yang terinfeksi,

4. Kehamilan bayi kurang dari tiga bulan yang terinfeksi akibat penularan vertikal akan diaborsi. Ini dilakukan untuk pertimbangan medis,

5. Tingkat infeksi diasumsikan konstan.

Berdasarkan asumsi tersebut maka rumusan model adalah sebagai berikut.

$$
\begin{aligned}
& \frac{d S_{m}}{d t}=\alpha N-\frac{\beta \cdot I_{m} \cdot S_{m}}{N}-\mu \cdot S_{m} \\
& \frac{d E_{m}}{d t}=\frac{\beta \cdot I_{m} \cdot S_{m}}{N}-(\gamma+\mu) \cdot E_{m} \\
& \frac{d I_{m}}{d t}=\gamma \cdot E_{m}-\theta \cdot I_{m}-\mu \cdot I_{m} \\
& \frac{d R_{m}}{d t}=\theta \cdot I_{m}-\mu \cdot R_{m} \\
& \frac{d I_{C}}{d t}=\varepsilon \cdot I_{m}-\rho \cdot I_{C}-\tau \cdot I_{C} \\
& \frac{d R_{C}}{d t}=\rho \cdot I_{C}-\tau \cdot R_{C}
\end{aligned}
$$

di mana $S_{m}, E_{m}, I_{m}, R_{m}$ adalah wanita usia subur yang Rentan-Laten-Infeksi-Sembuh, masing-masing, sedangkan $I_{C}, R_{C}$ masing-masing adalah bayi yang terinfeksi dan pulih. $\alpha$ adalah angka kelahiran wanita, $\beta$ adalah tingkat infeksi wanita yang terinfeksi terhadap wanita yang rentan, $\mu$ adalah tingkat kematian alami wanita, $\gamma$ adalah tingkat inkubasi dari wanita laten menjadi wanita yang terinfeksi infeksi, $\theta$ adalah tingkat kesembuhan dari wanita yang terinfeksi, $\varepsilon$ adalah proporsi angka kelahiran dari ibu yang terinfeksi, $\rho$ adalah angka kesembuhan anak dari infeksi, dan $\tau$ adalah angka kematian alami anak-anak. Untuk memenuhi makna biologis, semua parameter sistem bersifat nonnegatif. Untuk menganalisis sistem (1) akan lebih mudah jika menerapkan re-scale berikut ini.

$$
\bar{S}_{m}=\frac{S_{m}}{N}, \bar{E}_{m}=\frac{E_{m}}{N}, \bar{I}_{m}=\frac{I_{m}}{N}, \bar{R}_{m}=\frac{R_{m}}{N}, \bar{I}_{c}=\frac{I_{c}}{N}, \bar{R}_{c}=\frac{R_{c}}{N},
$$

sehingga dapat diperoleh sistem yang baru sebagai berikut (setelah menghilangkan tanda bar) 


$$
\begin{aligned}
& \frac{d S_{m}}{d t}=\alpha-\beta \cdot I_{m} \cdot S_{m}-\mu \cdot S_{m} \\
& \frac{d E_{m}}{d t}=\beta \cdot I_{m} \cdot S_{m}-(\gamma+\mu) \cdot E_{m} \\
& \frac{d I_{m}}{d t}=\gamma \cdot E_{m}-\theta \cdot I_{m}-\mu \cdot I_{m} \\
& \frac{d R_{m}}{d t}=\theta \cdot I_{m}-\mu \cdot R_{m} \\
& \frac{d I_{C}}{d t}=\varepsilon \cdot I_{m}-\rho \cdot I_{C}-\tau \cdot I_{C} \\
& \frac{d R_{C}}{d t}=\rho \cdot I_{C}-\tau \cdot R_{C}
\end{aligned}
$$

Ekuilibrium Bebas Penyakit. Mengambil sisi kanan sistem (3) sama dengan nol dan mengambil $\boldsymbol{I}_{\boldsymbol{m}}=\mathbf{0}$ dan $\boldsymbol{I}_{\boldsymbol{c}}=$ 0, sehingga diperoleh

$$
P_{0}\left(\frac{\alpha}{\mu}, 0,0,0,0,0\right)
$$

Setelah linearisasi, Jacobian dari sistem memberikan nilai eigen, sebagai berikut:

$$
\lambda_{1}=\lambda_{2}=-\mu, \lambda_{3}=-\rho-\tau, \lambda_{4}=-\tau, \lambda_{5}=\lambda_{50}, \lambda_{6}=\lambda_{60}
$$

di mana

$$
\lambda_{50}=\frac{-\left(\gamma \mu+2 \mu^{2}+\mu \theta\right)-\sqrt{\left(\gamma \mu+2 \mu^{2}+\mu \theta\right)^{2}-4 \mu\left(-\alpha \beta \gamma+\gamma \mu^{2}+\gamma \mu \theta+\mu^{3}+\mu^{2} \theta\right)}}{2 \mu}
$$

dan

$$
\lambda_{60}=\frac{-\left(\gamma \mu+2 \mu^{2}+\mu \theta\right)+\sqrt{\left(\gamma \mu+2 \mu^{2}+\mu \theta\right)^{2}-4 \mu\left(-\alpha \beta \gamma+\gamma \mu^{2}+\gamma \mu \theta+\mu^{3}+\mu^{2} \theta\right)}}{2 \mu}
$$

dari situ dapat disimpulkan bahwa kesetimbangan bebas penyakit $\boldsymbol{P}_{\mathbf{0}}$ stabil ketika

$$
-\alpha \beta \gamma+\gamma \mu^{2}+\gamma \mu \theta+\mu^{3}+\mu^{2} \theta>0 .
$$

Ekuilibrium Endemik. Mengambil ruas kanan sistem (3) sama dengan nol untuk memperoleh ekuilibrium endemik sistem yang diberikan oleh:

dengan

$$
P_{1}\left(S_{m}^{*}, E_{m}^{*}, I_{m}^{*}, R_{m}^{*}, I_{c}^{*}, R_{c}^{*}\right)
$$

$S_{m}^{*}=\frac{\gamma \mu+\gamma \theta+\mu^{2}+\mu \theta}{\beta \gamma}$

$E_{m}^{*}=\frac{\alpha \beta \gamma-\gamma \mu^{2}-\gamma \mu \theta-\mu^{3}-\mu^{2} \theta}{\beta \gamma(\gamma+\beta)}$

$I_{m}^{*}=\frac{\alpha \beta \gamma-\gamma \mu^{2}-\gamma \mu \theta-\mu^{3}-\mu^{2} \theta}{\beta\left(\gamma \mu+\gamma \theta+\mu^{2}+\mu \theta\right)}$

$R_{m}^{*}=\frac{\theta\left(\alpha \beta \gamma-\gamma \mu^{2}-\gamma \mu \theta-\mu^{3}-\mu^{2} \theta\right)}{\beta \mu\left(\gamma \mu+\gamma \theta+\mu^{2}+\mu \theta\right)}$

$I_{c}^{*}=\frac{\varepsilon\left(\alpha \beta \gamma-\gamma \mu^{2}-\gamma \mu \theta-\mu^{3}-\mu^{2} \theta\right)}{\beta\left(\gamma \mu \rho+\gamma \mu \tau+\gamma+\rho \theta+\gamma \tau \theta+\mu^{2} \rho+\mu^{2} \tau+\mu \rho \theta+\mu \tau \theta\right)}$

$R_{c}^{*}=\frac{\rho \varepsilon\left(\alpha \beta \gamma-\gamma \mu^{2}-\gamma \mu \theta-\mu^{3}-\mu^{2} \theta\right)}{\beta \tau\left(\gamma \mu \rho+\gamma \mu \tau+\gamma+\rho \theta+\gamma \tau \theta+\mu^{2} \rho+\mu^{2} \tau+\mu \rho \theta+\mu \tau \theta\right)}$

Dari kriteria keberadaan wanita yang terinfeksi atau dari persamaan (4) dapat diturunkan rasio reproduksi dasar yang menentukan ambang penyebaran penyakit. 


$$
\boldsymbol{R}_{\mathbf{0}}=\frac{\alpha \beta \gamma}{\mu(\gamma+\mu)(\mu+\theta)}
$$

Simulasi I. Simulasi numerik dilakukan dengan tujuan untuk melihat dinamika solusi dari sistem dengan memvariasikan nilai $\boldsymbol{\beta}$, tingkat infeksi dari wanita yang infeksi. Pertama, menghitung nilai parameter sistem yang sesuai dengan situasi nyata dan memenuhi kondisi pada $\boldsymbol{R}_{\mathbf{0}}$ seperti yang disajikan pada Tabel 1.

Tabel 1. Nilai Parameter

\begin{tabular}{lcc}
\hline \multicolumn{1}{c}{ Parameter } & Notasi & Nilai \\
\hline Tingkat kelahiran wanita & $\boldsymbol{\alpha}$ & 0.3 \\
\hline Tingkat kematian alami wanita & $\boldsymbol{\mu}$ & 0.3 \\
\hline Tingkat inkubasi & $\boldsymbol{\gamma}$ & 0.047 \\
\hline Tingkat kesembuhan wanita & $\boldsymbol{\theta}$ & 0.1 \\
\hline Presentase kelahiran janin & $\boldsymbol{\varepsilon}$ & 0.3 \\
\hline Tingkat kesembuhan janin & $\boldsymbol{\rho}$ & 0.1 \\
\hline Tingkat kematian alami janin & $\boldsymbol{\tau}$ & 0.2 \\
\hline
\end{tabular}

Ketika nilai $\boldsymbol{\beta}$ meningkat, terjadi transisi dinamika solusi; dari titik kesetimbangan bebas penyakit stabil yang ditunjukkan oleh Gambar 1(i) ke titik kesetimbangan endemik yang ditunjukkan oleh Gambar 1(ii), sedangkan keseimbangan bebas penyakit menjadi tidak stabil, yang merupakan bifurkasi pitchfork (lihat $[15,17]$ untuk referensi). Tingkat infeksi yang konstan tidak mempengaruhi banyak kejadian rubella pada populasi bayi seperti yang ditunjukkan pada Gambar 1(ii).
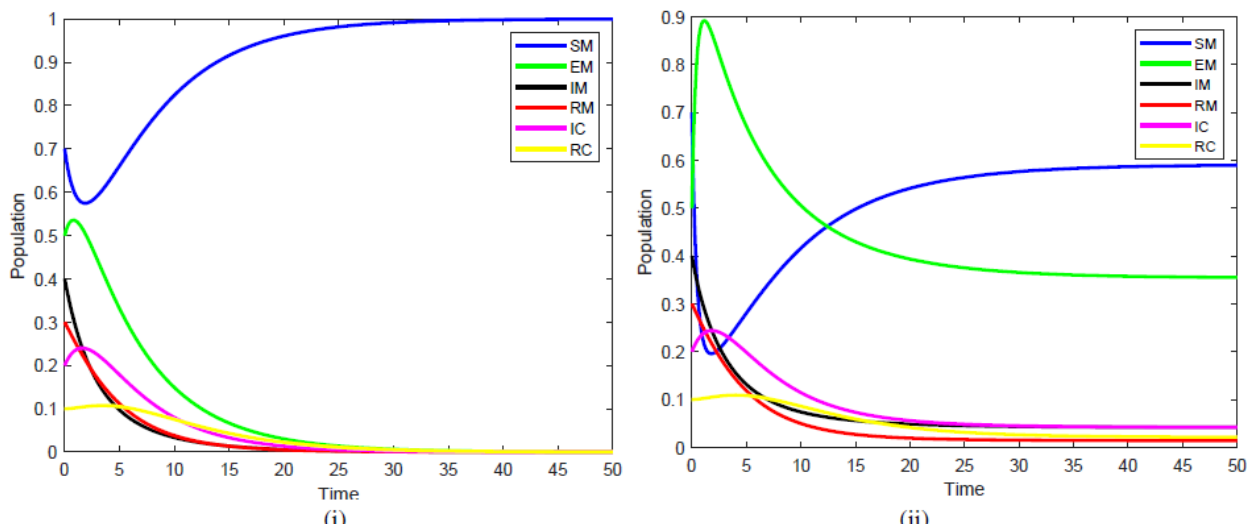

(ii)

Gambar 1. (i) Titik bebas penyakit yang stabil untuk $\beta=1\left(R_{0}<1\right)$ dan

(ii) Titik endemik yang stabil untuk $\beta=5\left(R_{0}>1\right)$.

\subsection{Model SEIR-IR dengan Faktor Musim}

Dengan memasukkan faktor musim ke sistem sebelumnya merupakan tahap awal dalam penelitian ini. Banyak penelitian tentang penyakit menular seperti rubella yang mempertimbangkan faktor musim selain mempertimbangkan nonlinier dan stokastisitas. (Lihat $[3,4,12,13,14]$ untuk referensi). Pada bagian ini, angka penularan dari wanita yang terinfeksi ke wanita rentan diasumsikan bersifat musiman dan diwakili oleh fungsi kosinus seperti yang dikemukakan oleh Olsen et.al. [4] sebagai berikut.

$$
\beta(t)=\beta_{0}\left(1+\beta_{1} \cos 2 \pi t\right)
$$

Sistem ini juga mengadopsi perilaku musiman karena variasi tahunan dalam lamanya masa inkubasi ekstrinsik (EIP) diperkenalkan di [13] sebagai berikut:

$$
\gamma=\frac{1-e^{-\mu t}}{\mu}
$$


di mana $\mu$ adalah angka kematian alami wanita. Setelah melakukan penskalaan serupa dengan model sebelumnya, maka model tersebut adalah dirumuskan sebagai berikut.

$$
\begin{aligned}
& \frac{d S_{m}}{d t}=\alpha-\beta_{0}\left(1+\beta_{1} \cos 2 \pi t\right) \cdot I_{m} \cdot S_{m}-\mu \cdot S_{m} \\
& \frac{d E_{m}}{d t}=\beta_{0}\left(1+\beta_{1} \cos 2 \pi t\right) \cdot I_{m} \cdot S_{m}-\frac{1-e^{-\mu t}}{\mu} E_{m}-\mu \cdot E_{m} \\
& \frac{d I_{m}}{d t}=\frac{1-e^{-\mu t}}{\mu} \cdot E_{m}-\theta \cdot I_{m}-\mu \cdot I_{m} \\
& \frac{d R_{m}}{d t}=\theta \cdot I_{m}-\mu \cdot R_{m} \\
& \frac{d I_{C}}{d t}=\varepsilon \cdot I_{m}-\rho \cdot I_{C}-\tau \cdot I_{C} \\
& \frac{d R_{C}}{d t}=\rho \cdot I_{C}-\tau \cdot R_{C}
\end{aligned}
$$

dimana $\beta_{0}>0$ dan $\beta_{1}>0$ adalah musim infeksi, sedangkan parameter lainnya memiliki arti yang sama dengan parameter pada sistem (3).

Simulasi II. Karena pekerjaan analitis dari sistem ini belum sepenuhnya selesai, simulasi numerik akan membantu memberikan wawasan awal tentang dinamika solusi. Menggunakan nilai parameter yang sama seperti pada Tabel 1 dan memvariasikan nilai $\beta_{1}$, hasil simulasi pada Gambar 2 .

Simulasi menunjukkan bahwa musim memberikan pengaruh yang kuat terhadap kejadian rubella pada bayi. Sementara itu, ada cukup banyak individu yang sembuh baik dari populasi wanita maupun bayi. Solusi endemik adalah orbit periodik yang stabil (ditunjukkan oleh perilaku osilasi, terutama untuk rentan, laten, dan infektif dari populasi wanita). Lebih menariknya lagi, ketika nilai $\beta_{1}$ semakin besar maka osilasi dari populasi laten, dan populasi wanita yang terinfeksi menjadi lebih luas.

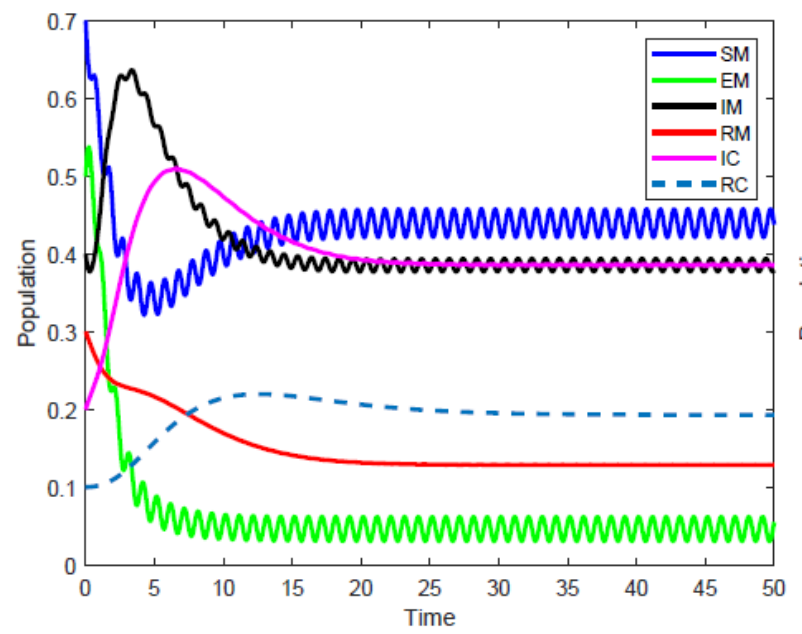

(i)

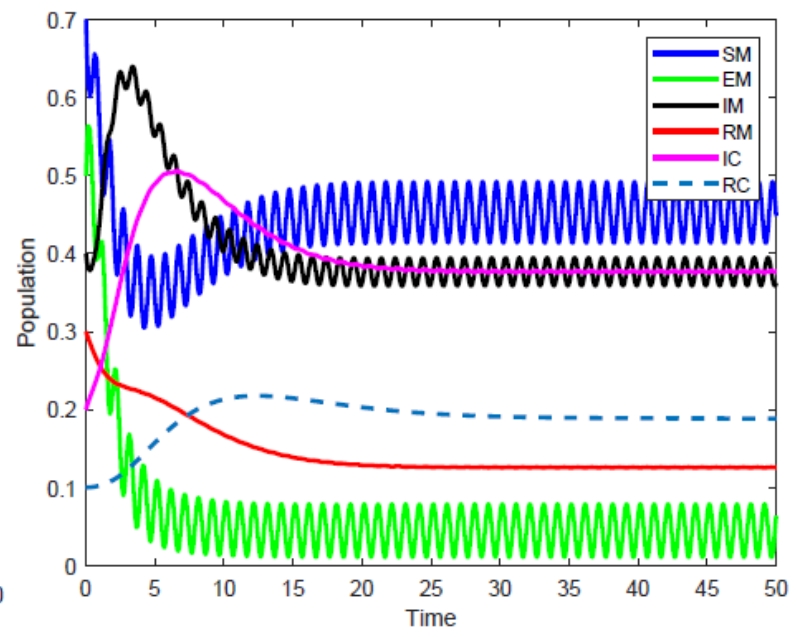

(ii)

Gambar 2. (i) Solusi untuk $\beta_{0}=1$ dan $\beta_{1}=0$ dan (ii) Solusi untuk $\beta_{0}=1$ dan $\beta_{1}=1.5$

\section{KESIMPULAN}

Dinamika penularan virus rubella melalui wanita usia subur kepada bayi baru lahir sangat penting dilakukan dan menarik untuk dipelajari. Tidak hanya untuk sudut pandang medis tetapi juga matematika. Studi tentang SEIR-IR dengan dan tanpa faktor musim akan memberikan ide baru tentang transmisi rubella dan analisis matematis. Hasil studi pemodelan dinamika virus rubella dengan memfokuskan pada populasi wanita usia subur dan bayi yang dilahirkan mereka memberikan informasi betapa berbahayanya risiko yang harus dialami oleh bayi yang baru lahir karena harus menyandang sindrom rubella bawaan. Hasil studi ini mengarahkan kita untuk mempertimbangkan dengan sungguh-sungguh tentang penting pemberian perlakuan agar situasi tersebut tidak terjadi atau setidaknya dapat dikurangi atau dicegah. Oleh karena itu, berdasarkan 
hasil yang diperoleh di paper ini, perlu dilakukan studi lanjutan dengan memberi perlakuan sebagai tindakan pencegahan terjadi sindrom rubella bawaan pada bayi yang dilahirkan. Salah satu yang dapat dilakukan adalah mengimplementasikan strategi pemberian program vaksinasi pada kelompok populasi tertentu.

\section{UCAPAN TERIMA KASIH}

Penulis berterima kasih kepada Kementerian Riset, Teknologi, dan Pendidikan Tinggi, Republik Indonesia atas dukungan dana untuk melakukan penelitian di bidang ini. (Nomor Kontrak: 193/SP2H/LT/DRPM/2019).

\section{DAFTAR PUSTAKA}

[1] F. T. Cutts, S. E. Robertson, J.-L. Diaz-Ortega, and R. Samuel, "Control of rubella and congenital rubella syndrome (CRS) in developing countries, part 1: burden of disease from CRS," Bulletin of World Health Organization, vol. 75, no. 1, pp. 55-68, 1997.

[2] E. S. Herini, Gunadi, A. Triono, A. W. E. Mulyadi, N. Mardin, Rusipah, Y. Soenarto, and S. E. Reef, "Hospital-based surveillance of congenital rubella syndrome in Indonesia," Eur J Pediatr., vol. 176, pp. 387-393, 2017.

[3] P. E. M. Fine and J. A. Clarkson, "Measles in England and Wales-I: An Analysis of Factors Underlying Seasonal Patterns," International Journal of Epidemiology, vol. 11, no. 1, pp. 1-14, 1982.

[4] L. F. Olsen, G. L. Truty, and W. M. Schaffer, "Oscillations and Chaos in Epidemics: A Nonlinear Dynamics Study of Six Childhood Diseases in Copenhagen, Denmark," Theoretical Population Biology, vol. 33, pp. 344-370, 1988.

[5] Z. Gao, J. G. Wood, M. A. Burgess, R. I. Menzies, P. B. McIntyre, and C. R. MacIntyre, "Models of strategies for control of rubella and congenital rubella syndrome - A 40 year experience from Australia," Vaccine, 31, pp. 691-697, 2013.

[6] H. Lee, T. Kayano, and H. Nishiura, "Predicting congenital rubella syndrome in Japan 2018-2019," Int. J. Infectious Diseases, vol. 82, pp. 1-5, 2019.

[7] C. J. E. Metcalf, O. N. Bjornstad, M. J. Ferrari, P. Klepac, N. Bharti, H. Lopez-Gatell, and B. T. Grenfell, "The epidemiology of rubella in Mexico: seasonality, stochasticity and regional variation,” Epidemiol. Infect. vol. 139, 1029-1038, 2011.

[8] Y. Wu, J. Wood, G. Khandaker, C. Waddington, and T. Snelling," Informing rubella vaccination strategies in East Java, Indonesia through transmission modelling," Vaccine, vol. 34, no. 46, pp. 5636-5642, 2016.

[9] A. R. McLean and R. M. Anderson, "Measles in developing countries Part I. Epidemiological parameters and patterns," Epidem. Inf. vol. 100, 111-133, 1988.

[10] D. Walker, H. Carter, and I. G. Jones, "Measles, mumps, and rubella: the need for a change in immunisation policy," British Med. J. vol. 292, pp. 1501-1502, 1986.

[11] M. J. Keeling and P. Rohani, Modeling Infectious Diseases in Humans and Animals, Princestone, NJ: Princestone University Press, 2008

[12] M. Keeling, P. Rohani, and B. T. Grenfell, "Seasonality forced disease dynamics explored as switching between attractors," Physica D, vol. 148, pp. 317-335, 2001

[13] P. Pongsumpun and I. M. Tang, "Effect of the Seasonal Variation in the Extrinsic Incubation Period on the Long Term Behavior of the Dengue Hemorraghic Fever Epidemic," Inter. J. Math. and Comp. vol. 1, no. 10, 483-489, 2007.

[14] J. Ma and Z. Ma, "Epidemic threshold conditions for seasonality forced SEIR models," Mathematical Biosciences and Engineering, vol. 3, no. 1, pp. 161-172, 2006.

[15] J. Hale and H. Kocak, Dynamics and Bifurcations, Springer-Verlag New York, Inc., 1996.

[16] R. M. May and R. M. Anderson, "Population biology of infectious diseases: Part I," Nature, vol. 280, pp. 361-367, 1979.

[17] C. Chicone, Ordinary Differential Equations with Applications, Springer-Verlag New York, Inc., 1999.

[18] S. Gao, Y. Liu, J. J. Nieto, and H. Andrade, Seasonality and Mixed Vaccination Strategy in Epidemic Model with Vertical Transmission, Math. Computers Simul. vol. 8, 1855 - 1868, 2011.

[19] N. Lambert, et. al., Rubella, The Lancet, vol. 385, No, 9984, 2297-2307, 2015.

[20] C. J. E. Metcalf et. al. The epidemiology of rubella in Mexico: seasonality, stochasticity and regional variation, Epidemiol. Infect. vol. 139, 1029 - 1038, 2011.

[21] Abadi, R. Artiono, B. P. Prawoto, The effects of vaccination to the dynamics of rubella virus with seasonality, Commun. Math. Biol. Neurosci. vol. 2020, 2020. 
